\title{
РАДИОЭКОЛОГИЧЕСКАЯ ОПАСНОСТЬ ДЛЯ НАСЕЛЕНИЯ В РАЙОНАХ РАСПРОСТРАНЕНИЯ ВЫСОКОРАДИОАКТИВНЫХ ГРАНИТОВ
}

\author{
Злобина Анастасия Николаевна ${ }^{1,2}$, \\ anastasiyazl@mail.ru
}

Рихванов Леонид Петрович', rikhvanov@tpu.ru

\section{Барановская Наталья Владимировна', nata@tpu.ru}

\section{Фархутдинов Исхак Мансурович², iskhakgeo@gmail.com}

\author{
Ванг Нанпинг, \\ 1996010992@cugb.edu.cn \\ 1 Национальный исследовательский Томский политехнический университет, \\ Россия, 634030, г. Томск, пр. Ленина, 30. \\ 2 Башкирский государственный университет, \\ Россия, 450074, г. Уфа, ул. Заки Валиди, 32. \\ 3 Китайский геологический университет, \\ Китай, 100083, г. Пекин, пр. Хайянь, 29.
}

Актуальность исследования обусловлена необходимостью объяснения высокой заболеваемости населения в районах распространения радиоактивных пород и почв. Исследование выполнено в рамках нового научного направления - медицинской геологии.

Целью работы является изучение масштабов радоновыделений в районах выхода на поверхность высокорадиоактивных гранитов, оценка их радиоэкологической опасности и медико-биологических последствий.

Объекты: геохимический и минералогический состав образцов гранитов, кор выветривания и почв, масштабы радоновыделений и частота заболеваемости в различных областях мира (г. Чжухай в китайской провинции Гуандун; г. Эшасьер во французском регионе Овернь) и Сибирского региона (г. Белокуриха Алтайского края; пгт. Колывань Новосибирской области).

Методы. В рамках исследования применялся широкий комплекс методов, включающий инструментальный нейтронно-активационный, рентгенофазовый анализы, гамма-спектрометрию, осколочную радиографию, электронную микроскопию, экспрессное измерение объёмной активности радона, расчет потока плотности радона, эквивалентной эффективной дозы и частоты вновь выявленных заболеваний (incidence).

Результаты. Проведено обобщение данных по воздействию ионизирующего излучения на организм человека. По результатам геохимических, минералогических, радиоэкологических и медико- статистических исследований выявлено, что в процессах коро- и почвообразования радионуклиды высвобождаются из структурных решеток акцессорных минералов и сорбируются на глинистых минералах. Данный процесс способствует повышению радоновыделений и радиационного фона. Дано объяснение возможных связей повышенных концентраций радионуклидов в подстилающих породах, почвах и высокой активности газа радона с показателями заболеваемости населения. При сопоставлении первичных показателей онкозаболеваемости у всех групп населения с общероссийскими и мировыми показателями отмечаются превышения уровня во всех исследуемых районах. К территориям «риска» по частоте заболеваемости раком легкого можно отнести Белокуриху в Алтайском крае и Колывань в Новосибирской области; раком носоглотки - провинцию Гуандун; раком кроветворной ткани - Колывань; анемиями - Гуандун; по врожденным порокам развития - Гуандун и Колывань.

\section{Ключевые слова:}

Радиация, уран, торий, радон, граниты, почвы, радиоэкологические проблемы, заболеваемость, радиоэкология, медицинская геология, геоэкология, Гуандун, Овернь, Белокуриха, Колывань.

\section{Введение}

Радиация - неотъемлемая составляющая окружающей среды человека. Биологические объекты испытывают влияние альфа-, бета- и гамма-радиоактивности, образующейся вследствие произвольного распада естественных (урана (U), тория (Th), радия $(\mathrm{Ra})$, радона $(\mathrm{Rn})$ и др.) и искусственных (цезия (Cs), стронция (Sr), америция (Am), плутония $(\mathrm{Pu})$ и др.) радионуклидов. Воздействие радиации на здоровье человека зависит от уровня поглощаемой дозы, продолжительности действия ионизирующих лучей на организм в целом и на отдельные его органы, радиочувствительности и радиорезистентности клеток, тканей, органов или всего организма к воздействию излучения.

Ионизирующая радиация - доказанный фактор риска злокачественных опухолей. Риск онкозаболеваний имеет повышенный уровень у людей, 
подвергающихся влиянию ионизирующей радиации всех видов [1].

Известно, что в средней годовой дозе облучения от естественных источников в большинстве стран $\mathrm{Rn}$ является основным дозообразующим фактором (более $80 \%$ ).

Многолетние исследования ООН НКДАР [2-4] показывают четкую зависимость заболеваемости раком легких от повышения концентраций вдыхаемого $\mathrm{Rn}$, особенно для рабочих горно-промышленных предприятий.

Мелкоклеточный рак легких является плохо прогнозируемым гистологическим типом рака легких, наиболее тесно связанным с бытовым Rn. Многолетние исследования выявили развитие такого типа злокачественных новообразований (ЗНО) легкого у разных групп населения (не курящие, женщины, дети и др.) во многих странах [5].

Помимо ЗНО легкого высокие концентрации радионуклидов в окружающей среде провоцируют такие заболевания, как рак носоглотки, рассеянный склероз, саркому кости и др. Радиация обусловливает гипоплазию костного мозга. В основе гипоплазии кроветворной ткани лежит необратимое повреждение и гибель стволовых клеток, вплоть до их полного исчезновения, наблюдающегося при аплазии. Это может привести к развитию гипо- или апластических анемий и $3 \mathrm{HO} \mathrm{кроветвор-}$ ной ткани (лейкоз/лейкемия и др.).

Доказана положительная корреляция между активностями $\mathrm{Rn}$ в домах и заболеваемостью лейкемией у детей в разных странах $[6,7]$. Повышенный уровень данной патологии отмечен в Швеции, Финляндии, Норвегии и др. Известно, что страны Скандинавии характеризируются повышенными дозовыми нагрузками и фоновыми концентрациями Rn как в воздухе, так и в воде [8].

В пределах региона Овернь (Франция) расположены урансодержащие граниты (Де Бовуар). В результате процессов корообразования на этих гранитах формируются почвы и инфильтруются подземные воды, наследующие естественные радиоактивные элементы (ЕРЭ), что приводит к высоким концентрациям $\mathrm{Rn}\left(300 \mathrm{Б \kappa} / \mathrm{m}^{3}\right)$. Увеличение смертности от лейкемии установлено в тех регионах Франции, где наблюдается повышенные эманации $\mathrm{Rn}[9]$.

В районах распространения пород с высокой концентрацией ЕРЭ также отмечается повышенная заболеваемость и смертность от рака носоглотки. Сопоставление карт распределения смертности от рака носоглотки в Китае за 1973-1975 гг. и распределения содержания U и Th в верхнем слое почв на территории Китая выявило связь смертности от ЗНО носоглотки с повышенным содержанием радионуклидов в почвах [10].

Торону $\left({ }^{220} \mathrm{Rn}\right)$ - продукту распада ${ }^{232} \mathrm{Th}$, как радиоэкологическому фактору уделяется меньше внимания, чем ${ }^{222} \mathrm{Rn}$ - дочернему продукту ${ }^{238} \mathrm{U}$. Однако ряд ученых относят торон $\kappa$ факторам радиационного риска, особенно в помещениях, постро- енных из материала, обогащенного ${ }^{232} \mathrm{Th}$ [11 и др.]. Медико-биологические проблемы в районах с повышенным радиационным фоном связаны не только с активностями ${ }^{222} \mathrm{Rn}$ и ${ }^{220} \mathrm{Rn}$, а также с концентрациями $\mathrm{U}$ и $\mathrm{Th}$ в воде и продуктах питания.

Например, в Южной Африке из-за высоких концентраций U в питьевых водах и мясе сельскохозяйственных животных, в частности в баранине, наблюдается повышенный риск заболеваемостью лейкемией, особенно у детей. Причем, большую опасность несет загрязнение питьевых вод, нежели продуктов питания [12].

Th имеет тенденцию к ретикулоэндотелиальному типу распределения в организме и депонированию в легких, лимфоидной ткани, костном мозге и скелете. Данный радионуклид может адсорбироваться на поверхности клеток, вызывая опухоли печени, остеосаркому [13 и др.].

\section{Материалы и методы}

Были изучены районы распространения высокорадиоактивных гранитов с различной спецификой (урановой, ториевой и уран-ториевой) (рис. 1).

Геологическое описание районов исследования

Район г. Белокуриха, Алтайский край, Россия. Белокурихинский интрузивный комплекс расположен в зоне перехода от Бийско-Барнаульской впадины к Алтае-Саянской складчатой области.

На основании U-Pb метода по цирконам установлено, что возраст белокурихинского комплекса $233 \pm 12$ млн лет [14]. Породы Белокурихинского комплекса имеют содержание $\mathrm{SiO}_{2}$ от 52,77 до $71,85 \%$, высокую сумму щелочей $\mathrm{K}_{2} \mathrm{O}+\mathrm{Na}_{2} \mathrm{O}$ (более $8 \%$ ). Гранитоиды обогащены легкими редкоземельными радиоактивными элементами (Th 21 г/т, U - 6 г/т, Th/U - 3,5) и летучими компонентами, такими как F, B.

В пределах Искровско-Белокурихинской U-редкометалльной рудной зоны прогнозируется месторождение вольфрама, также зона характеризуется повышенной радиоактивностью и относится к радоноопасным территориям [14]. В этой полосе локализуются эндогенные проявления $\mathrm{U}, \mathrm{a}$ также уникальное Белокурихинское месторождение радоновых вод, используемое в бальнеологических целях на курортах г. Белокурихи.

Район г. Новосибирска и пгт. Колывань, Новосибирская область, Россия. Новосибирск и расположенный в 46 км от него пгт. Колывань находятся в юго-восточной окраине Западно-Сибирской равнины, в области сопряжения одноименной плиты с горными сооружениями Алтае-Саянской складчатой области (западной обнаженной части границы Колывань-Томской складчатой зоны), в пределах Обского гранитоидного массива.

Возраст Колыванских гранитов составляет $249,5 \pm 0,9$ млн лет [15]. В пределах гранитоидного массива выделяются две основные разновидности гранитов: роговообманково-биотитовые, развитые в основном в районе г. Новосибирска, и более свет- 


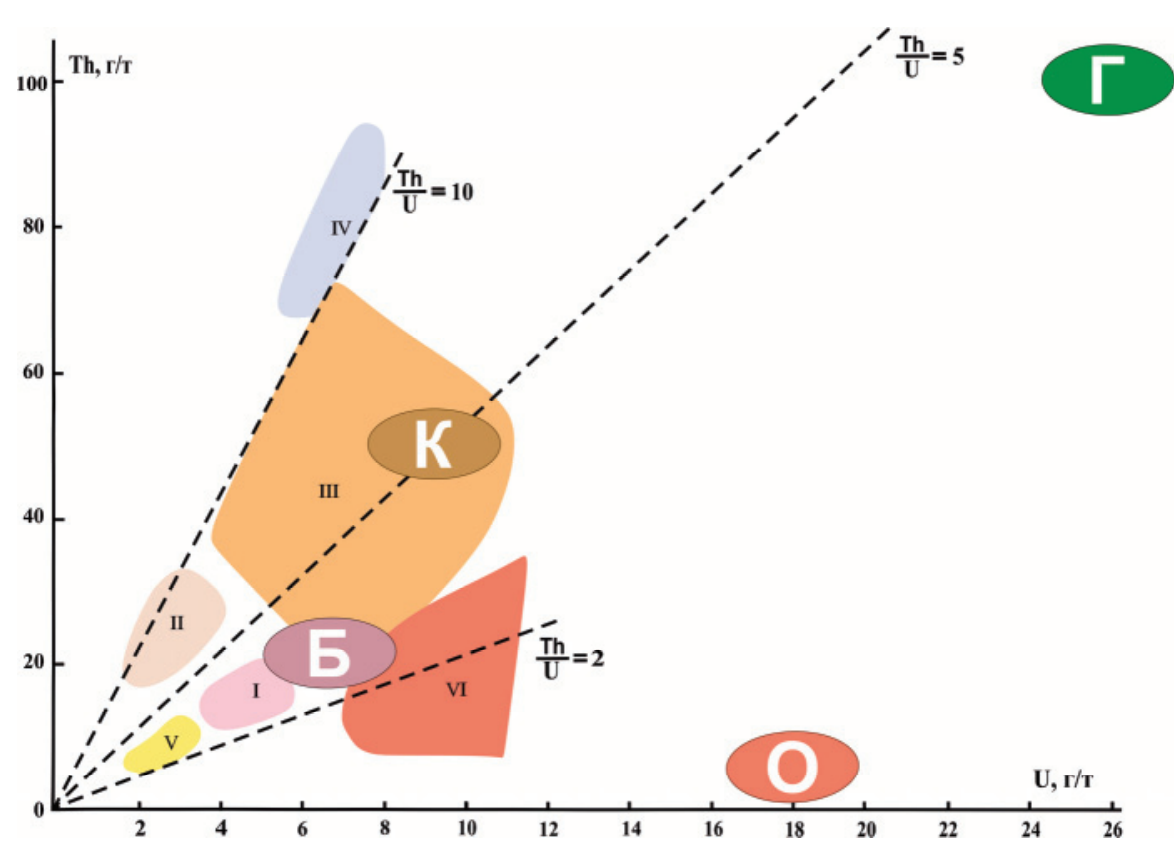

Рис.1. Главнейшие радиогеохимические типы гранитов и положение на них гранитов исследуемых районов (по Л.В. Комлеву, А.А. Смыслову с дополнениями авторов). Поля геохимических типов гранитов: $I$ - нормальнорадиоактивные, $T h / U=2,5-4,5$; II - noвышеннорадиоактивные, Th/U=6-10; III - высокорадиоактивные редкометалльные, Th/U>5-10; IV - высокорадиоактивные ториеносные, Th/U>10; V - слаборадиоактивные плагиограниты, Th/U<2-5; VI - высокорадиоактивные ураноносные, $T h / U=1-2$. Средние данные по изученным гранитам: 5 - района г. Белокуриха, Алтайский край, Россия; $K$ - района пгт. Кольвань, Новосибирская область, Россия; $\Gamma$ - района г. Чжухай, провинция Гуандун, Китай; О - райна г. Эшасьер, регион Овернь, Франиия

Fig. 1. The main radiogeochemical types of granites and the position of the studied granites (according to L.V. Komlev, A.A. Smyslov with additions of the authors). Fields of geochemical types of granites: $I$ - normal radioactive, Th/U=2,5-4,5; II - elevated radioactive, $T h / U=6-10 ; I I I-h i g h l y$ radioactive rare metal, $T h / U>5-10 ; I V$ - highly radioactive thoriogenic, $T h / U>10 ; V$ - weakly radioactive plagiogranites, Th/U<2-5; VI - highly radioactive uranium-bearing, Th/U=1-2. Average data on the studied granites: $B-B e l o k u r i k h a$, Altai Krai, Russia; K - Kolyvan, Novosibirsk region, Russia; $\Gamma$-Zhuhai, Guangdong province, China; O - Easier, Auvergne, France

лые разности - биотитовые, а местами двуслюдистые граниты, наиболее характерные для Колыванского участка. В гранитах известны многочисленные проявления и рудопроявления $\mathrm{U}$ и $\mathrm{Th}$, обычно приуроченные к приконтактовым частям интрузий, к зонам грейзенизации, гидротермальных изменений, брекчирования, корам выветривания [16].

В составе образований нижнего структурного этажа на рассматриваемой площади достаточно широко распространены граниты, «подстилающие» более 50 \% основной территории города Новосибирска и пгт. Колывань. Эти граниты характеризуются повышенными концентрациями естественных радионуклидов (Th -47 г/т, U -9 г/т, $\mathrm{Th} / \mathrm{U}-5,2)$. По гранитам развиты площадные и линейные коры выветривания.

Район г. Чжухай, провинция Гуандун, Китай. Провинция Гуандун располагается в пределах западной дуги вокруг Тихоокеанского металлогенического рудного пояса. В пределах территории рудного поля широко проявлен кислый и, в меньшей степени, субщелочной интрузивный магматизм.

Территория города Чжухай и его окрестностей расположена преимущественно на биотитовых, порфировых и монцонитовых гранитах юрского возраста. Щелочные граниты имеют высокую кон- центрацию щелочей $\mathrm{Na}_{2} \mathrm{O}+\mathrm{K}_{2} \mathrm{O}(\sim 8 \%)$, но относительно низкое содержание кремнезема $\mathrm{SiO}_{2}$ (от 63 до $75 \%$ ), также обогащены легкими редкими землями (до 500 г/т) и радиоактивными элементами (Th - 100 г/т, U - 26 г/т, Th/U - 3,8) [17, 18].

В связи с гумидным климатом, обуславливающим интенсивные процессы выветривания пород, по гранитам образуются коры выветривания мощностью до 50 м. В районе г. Чжухай находится несколько редкоземельных месторождений кор выветривания ионно-сорбционного типа [19].

Район г.Эшасьер, регион Овернь, Франиия. Северная часть Центрального французского массива (Овернское ядро) состоит из кристаллических сланцев, пронизанных гранитными интрузиями, штоками, в том числе Де Бувуар (De Beauvoir) размером 0,2 м $^{2}$, в пределах которого разрабатывается месторождение Эшасьер (Echassiere).

Со среднего карбона до среднего триаса в подвижных поясах доминировали коллизионные обстановки, проходило становление металлоносных массивов гранитоидов. Эти процессы сформировали в массиве штокверки рудных полей Эшасьер. Штокверки состоят из двуслюдяных гранит-порфиров, возраст которых 305-293 млн лет [20].

Содержания породообразующих соединений в позднекаменноугольных литий-фтористых редко- 
металльных гранитах Бувуар в \%: $\mathrm{SiO}_{2}-66,6$, $\mathrm{Al}_{2} \mathrm{O}_{3}-17,6, \mathrm{Fe}_{2} \mathrm{O}_{3}-0,1, \mathrm{FeO}-0,3, \mathrm{CaO}-0,6$, $\mathrm{Na}_{2} \mathrm{O}-5,8, \mathrm{~K}_{2} \mathrm{O}-3,18, \mathrm{P}_{2} \mathrm{O}_{5}-1,4, \mathrm{Li}_{2} \mathrm{O}-1$. Граниты отличаются повышенными концентрациями $\mathrm{F}$, $\mathrm{Li}, \mathrm{Rb}, \mathrm{Sn}, \mathrm{Ta}, \mathrm{W}, \mathrm{U}$ [21]. Содержание Th составляет 1,7 г/т, U - 18 г/т, Th/U - 0,1. Смещение Th/U отношения в сторону U обусловлено метаморфическими преобразованиями гранитов Бувуар [22].

Отбор проб. Для геохимических и минералогических исследований на участках развития данных пород был произведен отбор 18 проб по 4 геологическим разрезам. Дальнейшее изучение пород и почв проводилось на базе ИШПР НИ ТПУ с использованием методов электронной микроскопии, осколочной радиографии, инструментального нейтронно-активационного и рентгенофазового анализов.

Непосредственно в полевых условиях в точках отбора проб производился гамма-спектрометрический анализ прибором SatisGeo GS-512 со сцинтилляционным блоком детектирования на основе кристалла йодистого натрия $\mathrm{NaI}(\mathrm{Tl})$. Также измерялся Rn при помощи прибора радиометра «Альфарад» марки РРА-01M-01, предназначенного для экспрессных измерений объёмной активности ${ }^{222} \mathrm{Rn}$ в воздухе. Предел допускаемой основной относительной погрешности в поддиапазоне от 20 до $100 \mathrm{Б \kappa} / \mathrm{m}^{3} \pm 30 \%$.

Аналитические методы. Анализ содержания ЕРЭ проводился методом инструментального нейтронно-активационного анализа (ИНАА) с использованием исследовательского ядерного реактора НИ ТПУ (аналитики - А.Ф. Судыко, Л.В. Богутская). Данный метод эффективен для определения радиоактивных элементов.

Метод электронной микроскопии производился при помощи электронного микроскопа Hitachi S-3400N.

При методе осколочной радиографии на детекторе фиксировались треки от реакции деления ядер атомов ${ }^{235} \mathrm{U}$ под действием тепловых нейтро- нов. В качестве детектора использовалась натуральная слюда - флогопит.

Рентгенофазовый анализ проводился для определения минерального состава почв с помощью установки D2 PHASER компании Bruker. Для pacшифровки рентгенограмм применялись программный пакет Eva на основе баз данных дифрактометрии PDF2 Международного центра дифракционных данных (ICDD, Denver, USA).

Обработка результатов. Данные по заболеваемости в г. Белокуриха Алтайского края за 2014-2016 гг. были предоставлены центральной городской больницей г. Белокуриха, по заболеваемости в пгт. Колывань Новосибирской области за 2011-2016 гг. - Колыванской центральной районной больницей. Также была использована информация из 17 опубликованных источников по заболеваемости.

Для расчета частоты вновь выявленных заболеваний, собственно заболеваемости (incidence), использовалась методика расчета показателей заболеваемости, при которой число впервые зарегистрированных случаев заболеваний за год делилось на среднегодовую численность населения исследуемого района (города) и умножалось на 100000.

\section{Результаты и обсуждение}

Геохимические особенности изученных образцов по данным ИНАА и гамма-спектрометрии представлены в табл. 1. Выявлена различная специфика распределения ЕРЭ по профильным разрезам в исследуемых районах. Наблюдаются неравномерные распределения ЕРЭ по профилю. Значение Th/U также меняется по горизонтам, что может свидетельствовать о различном геохимическом поведении U и Th в условиях смены окислительно-восстановительных реакций.

Исследуемые породы и продукты их выветривания имеют различные уровни накопления Th и U. Максимум содержания Th и U в гранитах на-

Таблица 1. Средние содержания ЕРЭ (г/m) и торий-урановое (Th/U) отношение в гранитоидах, корах выветривания и почвах в исследуемых регионах по данным гамла-спектрометрии и ИНАА

Table 1. Average contents of $U, T h \mathrm{bl}(\mathrm{g} / \mathrm{t})$ and $\mathrm{Th} / \mathrm{U}$ in granitoids, weathering crusts and soils of the studied regions according to gamma spectrometry and INAA

\begin{tabular}{|c|c|c|c|c|c|c|c|c|c|c|c|c|c|c|c|c|c|c|}
\hline $\begin{array}{l}\text { Pайон исследования } \\
\text { Study area }\end{array}$ & \multicolumn{3}{|c|}{$\begin{array}{l}\text { Граниты } \\
\text { Granites }\end{array}$} & \multicolumn{3}{|c|}{$\begin{array}{l}\text { Выветрелые } \\
\text { граниты } \\
\text { Weathered } \\
\text { granites }\end{array}$} & \multicolumn{3}{|c|}{$\begin{array}{c}\text { Зона дезин- } \\
\text { теграции } \\
\text { Disintegra- } \\
\text { tion zone }\end{array}$} & \multicolumn{3}{|c|}{$\begin{array}{c}\text { Зона дресвы } \\
\text { Granitic } \\
\text { subsoil }\end{array}$} & \multicolumn{3}{|c|}{$\begin{array}{c}\text { Глина } \\
\text { Clay }\end{array}$} & \multicolumn{3}{|c|}{$\begin{array}{l}\text { Почва } \\
\text { Soil }\end{array}$} \\
\hline \multirow{2}{*}{$\begin{array}{l}\text { Район г. Белокуриха (Алтайский край, Россия) } \\
\text { Belokurikha (Altai krai, Russia) }\end{array}$} & $\mathrm{U}$ & Th & $\mathrm{Th} / \mathrm{U}$ & $\mathrm{U}$ & Th & $\mathrm{Th} / \mathrm{U}$ & $\mathrm{U}$ & Th & $\mathrm{Th} / \mathrm{U}$ & $\mathrm{U}$ & Th & $\mathrm{Th} / \mathrm{U}$ & $\mathrm{U}$ & Th & $\mathrm{Th} / \mathrm{U}$ & $\mathrm{U}$ & Th & $\mathrm{Th} / \mathrm{U}$ \\
\hline & 6,4 & 21,1 & 3,3 & 9,7 & 37 & 3,8 & 8 & 53 & 6,6 & 10 & 30 & 2,9 & 11,4 & 58,8 & 3,3 & 8,6 & 37 & 4,3 \\
\hline $\begin{array}{l}\text { Район пгт. Колывань (Новосибирская обл., Россия) } \\
\text { Kolyvan (Novosibirsk oblast, Russia) }\end{array}$ & 9,6 & 34 & 3,5 & 15,6 & 73 & 4,7 & 8 & 32 & 3,9 & 10 & 47 & 4,6 & 10,6 & 57,2 & 5,4 & 5 & 15 & 3 \\
\hline $\begin{array}{l}\text { Район г. Чжухай (пров. Гуандун, КНР) } \\
\text { Zhuhai (province Guangdong, China) }\end{array}$ & 26,1 & 100 & 3,8 & 12,4 & 50,4 & 4 & - & - & - & - & - & - & 8,5 & 53,4 & 6,2 & 7 & $\begin{array}{c}45, \\
3\end{array}$ & 6,5 \\
\hline $\begin{array}{l}\text { Район г. Эшасьер (рег. Овернь, Франция) } \\
\text { Echassieres (Auvergne region, France) }\end{array}$ & $18^{2}$ & $1,7^{2}$ & 0,1 & - & - & - & - & - & - & - & - & - & - & - & - & 6,5 & 4,6 & 0,7 \\
\hline Среднее по миру/Global averages & $3,9^{1}$ & $18^{1}$ & 4,6 & - & - & - & - & - & - & - & - & - & $4,3^{1}$ & $14^{1}$ & 3,2 & $1^{3}$ & $5^{3}$ & 5 \\
\hline
\end{tabular}

- нет данных; ${ }^{1}-$ по данным H.A. Григорьева [23]; ${ }^{2}-$ nо данным M. Cипеу [22]; ${ }^{3}-$ nо данныл H.J.M. Bowen [24].

- no data; ${ }^{1}$ - according to N.A. Grigoriev [23]; ${ }^{2}$ - according to M. Cuney [22]; ${ }^{3}$ - according to H.J.M. Bowen [24]. 
блюдается в образцах из провинции Гуандун. Высокие концентрации Th для выветрелых гранитов характерны в районе г. Белокуриха, U - для района пгт. Колывань. Глина в районе г. Белокуриха имеет высокие содержания ЕРЭ относительно других исследуемых районов. Максимум Th в почве наблюдается в провинции Гуандун, U - в районе г. Белокуриха и провинции Гуандун.

По радиогеохимическому типу исследуемые граниты относятся к различным группам: граниты Белокурихинского и Колыванского комплексов к высокорадиоактивным редкометальным, граниты Бувуар (г. Эшасьер, Франция) - к высокорадиоактивным ураноносным, граниты Чжухая (провинция Гуандун, Китая) - к высокорадиоактивным ториевым (рис. 1).

Минералогический состав. Для всех исследуемых гранитов породообразующими минералами являются: кварц, альбит, микроклин, ортоклаз, мусковит и биотит. В колыванских гранитах присутствует флогопит.

В корах выветривания определены вторичные минералы: каолинит, монтмориллонит, иллит, хлорит, вермикулит. Цеолит был идентифицирован в образцах Белокурихинского и Колыванского массивов, гипс и диккит (группа каолинита) - в образцах Колыванского массива, гиббсит и гематит в образцах из провинции Гуандун.

Минералами-концентраторами ЕРЭ являются акцессорные минералы, представленные в табл. 2 . Монацит, циркон встречаются во всех исследуе- мых гранитах и продуктов их выветривания; церит присутствует в Колыванских образцах; ксенотим, торит, лопарит определены в пробах из Чжухая; граниты и почвы района Эшасьер отличаются присутствием танталита и колумбита.

Перечисленные акцессорные минералы в меньшем количестве наблюдаются в горизонтах кор выветривания и почвах. В процессе выветривания гранитов происходит изменение форм нахождения $\mathrm{U}$ и Th. Из форм, входящих в кристаллические решетки минералов, они переходят в неструктурные (сорбированные и др.). Особенно данный процесс характерен для U, так как данный элемент становится более мобильным и сорбируется на глинистых минералах (каолинит, монтмориллонит, вермикулит и др.) [25]. Это подтверждается результатами осколочной радиографии, показывающими равномерное распределение треков, что свидетельствует о сорбции $\mathrm{U}$ (рис. 2). Данный процесс способствует повышению активностей $\mathrm{Rn}$ - продукта распада $\mathrm{U}$.

Эксперименты П.С. Микляева показали, что глинистые породы представляют собой мощный генератор свободного Rn в геологической среде [26].

\section{Радиоэкологическая характеристика} и радиоэкологические риски

Территории с повышенным естественным радиационным фоном следует рассматривать в первую очередь с позиций потенциальной радоновой опасности. Также необходимо учитывать и другие признаки радиоэкологического риска.

Таблица 2. Присутствие акиессорных минералов-концентраторов ЕРЭ в исследуемых образиах

Table 2. $\quad$ Accessory minerals-concentrators of radionuclides in the studied samples

\begin{tabular}{|c|c|c|c|c|c|c|}
\hline \begin{tabular}{|r} 
Paйон исследования \\
Sample \\
Study area
\end{tabular} & $\begin{array}{l}\text { Граниты } \\
\text { Granites }\end{array}$ & $\begin{array}{c}\text { Выветрелые } \\
\text { граниты } \\
\text { Weathered } \\
\text { granites }\end{array}$ & $\begin{array}{c}\text { Зона дезинте- } \\
\text { грации } \\
\text { Disintegration } \\
\text { zone }\end{array}$ & $\begin{array}{l}\text { Зона дресвы } \\
\text { Granitic sub- } \\
\text { soil }\end{array}$ & $\begin{array}{c}\text { Глина } \\
\text { Clay }\end{array}$ & $\begin{array}{c}\text { Почва } \\
\text { Soil }\end{array}$ \\
\hline $\begin{array}{l}\text { Район г. Белокуриха } \\
\text { (Алтайский край, Россия) } \\
\text { Belokurikha (Altai krai, Russia) }\end{array}$ & \multicolumn{6}{|c|}{$\begin{array}{l}\text { Циркон, Монацит } \\
\text { Zircon, Monazite }\end{array}$} \\
\hline $\begin{array}{l}\text { Район пгт. Колывань } \\
\text { (Новосибирская обл., Россия) } \\
\text { Kolyvan (Novosibirsk oblast, Russia) }\end{array}$ & \multicolumn{3}{|c|}{$\begin{array}{l}\text { Циркон, Монацит, Церит } \\
\text { Zircon, Monazite, Cerite }\end{array}$} & \multicolumn{3}{|c|}{$\begin{array}{l}\text { Циркон, Церит } \\
\text { Zircon, Cerite }\end{array}$} \\
\hline $\begin{array}{l}\text { Район г. Чжухай (пров. Гуандун, КНР) } \\
\text { Zhuhai (province Guangdong, China) }\end{array}$ & $\begin{array}{c}\text { Циркон } \\
\text { Монацит } \\
\text { Ксенотим } \\
\text { Торит } \\
\text { Лопарит (РФА) } \\
\text { Zircon } \\
\text { Monazite } \\
\text { Xenotim } \\
\text { Thorite } \\
\text { Loparite (XRD) }\end{array}$ & \begin{tabular}{|c|} 
Циркон \\
Монацит \\
Ксенотим \\
Торит \\
Лопарит (РФА) \\
Zircon \\
Monazite \\
Xenotim \\
Thorite \\
Loparite (XRD)
\end{tabular} & $\begin{array}{c}\text { Циркон } \\
\text { Монацит } \\
\text { Ксенотим } \\
\text { Лопарит } \\
\text { (РФА) } \\
\text { Zircon } \\
\text { Monazite } \\
\text { Xenotim } \\
\text { Loparite } \\
\text { (XRD) }\end{array}$ & \multicolumn{3}{|c|}{$\begin{array}{c}\text { Циркон } \\
\text { Монацит } \\
\text { Ксенотим } \\
\text { Zircon } \\
\text { Monazite } \\
\text { Xenotim }\end{array}$} \\
\hline $\begin{array}{l}\text { Район г. Эшасьер (рег. Овернь, Франция) } \\
\text { Echassieres (Auvergne region, France) }\end{array}$ & \begin{tabular}{|c|} 
Циркон \\
Монацит \\
Танталит (РФА) \\
Колумбит (РФА) \\
Касситерит (РФА) \\
Zircon \\
Monazite \\
Tantalite (XRD) \\
Columbite (XRD) \\
Cassiterite (XRD)
\end{tabular} & \multicolumn{3}{|c|}{$\begin{array}{l}\text { Циркон } \\
\text { Монацит } \\
\text { Zircon } \\
\text { Monazite }\end{array}$} & & \begin{tabular}{|c} 
Циркон \\
Монацит \\
Танталит (РФА) \\
Колумбит (РФА) \\
Касситерит (РФА) \\
Zircon \\
Monazite \\
Tantalite (XRD) \\
Columbite (XRD) \\
Cassiterite (XRD)
\end{tabular} \\
\hline
\end{tabular}

РФА - по даннылм рентгенофазового анализа.

$X R D$-according to X-Ray Phase Analysis. 
a)

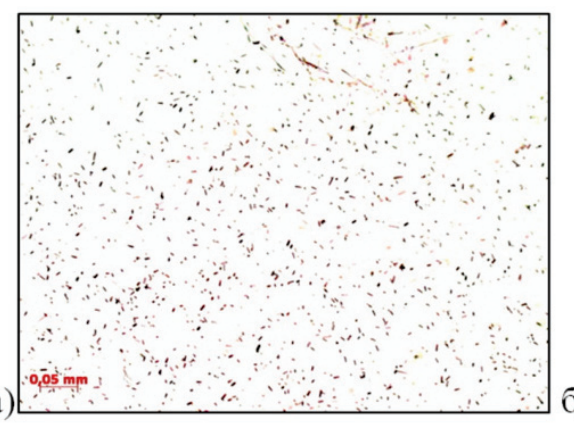

б)

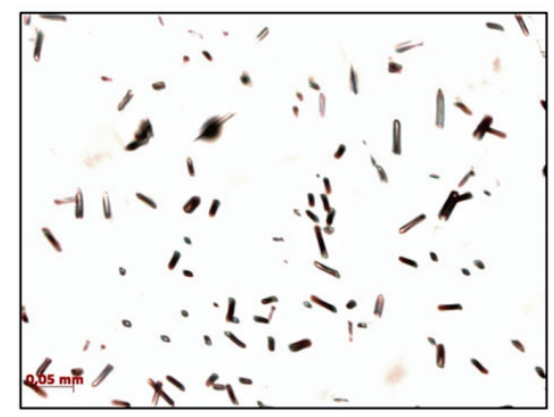

Pис. 2. Распределение U в образие почв г. Чжухай по данныл осколочной радиографии. Детектор-слюда: а) увеличение 20Х, б) увеличение $90 \mathrm{X}$

Fig. 2. Uranium distribution pattern in the sample of soil from Guangdong Province based on f-radiography. Detector- mica: a) lens of 20X, b) lens of $90 \mathrm{X}$

В исследуемых районах отмечена напряженная радиоэкологическая обстановка, связанная с геологическими образованиями, сложенными высокорадиоактивными гранитами, специализированными на U и Th; зонами интенсивного выветривания гранитов, что способствует увеличению активности $\mathrm{Rn}$; наличием радиоактивных аномалий и рудопроявлений $\mathrm{U}$; бассейнами радоновых вод и использованием радиоактивной воды в быту; интенсивной эксхаляцией (плотностью потока) ${ }^{222} \mathrm{Rn}$ с поверхности; областями повышенного эманирования ${ }^{222} \mathrm{Rn}$ (разрывные нарушения, зоны трещиноватости и т. п.); высокой активностью торона $\left({ }^{220} \mathrm{Rn}\right)$ за счет распространения ториеносных пород; использованием строительных материалов с

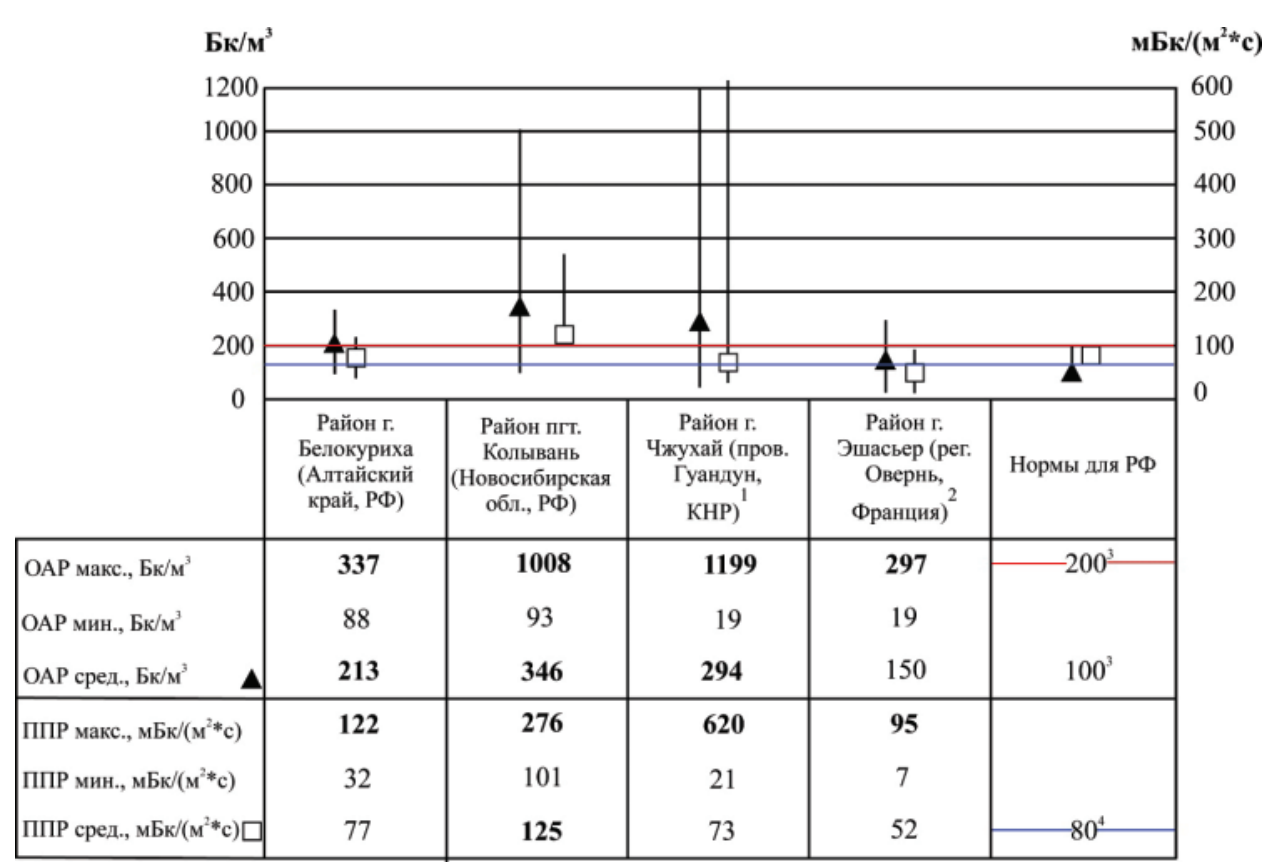

повышенной концентрацией ЕРЭ; значениями МЭД и ЭЭД, превышающими норму НКДАР ООН.

Отметим также, что в процессах выветривания гранитоидов эманации и эсхаляции ${ }^{222} \mathrm{Rn}$ в разы усиливаются за счет высвобождения ${ }^{238} \mathrm{U}$ из структурных решеток минералов и перехода его в другие формы нахождения (например, сорбированные).

Данные, полученные нами при помощи прибора радиометра $\mathrm{Rn}$ «Альфарад» в сентябре 2017 г. в районах г. Белокуриха и г. Новосибирск, результаты исследований N. Wang в районе г. Чжухай и S. Billon в районе г. Эшасьер, а также расчетные данные плотности потока $\mathrm{Rn}$ представлены на рис. 3.

' по данным N. Wang [27]; ${ }^{2}$ по данным S. Billon [28]; ${ }^{3}$ нормы радиационной безопасности (НРБ-99) [29]; ${ }^{4}$ СП 11-102-97 «Инженерноэкологические изыскания для строительства» [30].

${ }^{1}$ according to N. Wang [27]; ${ }^{2}$ according to S. Billon [28]; ${ }^{3}$ Radiation Safety Standards (NRB-99) [29]; ${ }^{4}$ SP 11-102-97 «Engineering and environmental surveys for construction" [30].

Puс. 3. График данных измерений объемной активности Rn (OAP) и расчета плотности потока Rn (ППР) в исследуемых районах

Fig. 3. Diagram of RVA measurements and RFD measurements in the studied areas 
В целом средние показания для ОАР во всех исследуемых районах превышают допустимый уровень для РФ в 100-200 Бк/м ${ }^{3}$, установленный в НРБ-99. Обычно в наружном воздухе ОАР у поверхности земли составляет в среднем $5-10 \mathrm{Б \kappa} / \mathrm{m}^{3}$.

Средние показатели ППР соответствуют уровню

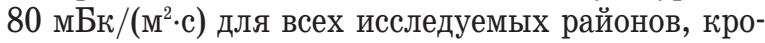
ме пгт. Колывань в Новосибирской области. В некоторых точках наблюдаются аномально высокие

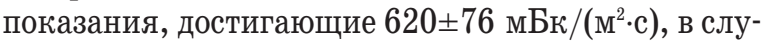
чае района г. Чжухай в Китае.

Высокорадиоактивные зоны чаще всего расположены вблизи зон разрывных нарушений. В Белокурихе такие места находятся в районах ул. Алтайской и ул. Эйхе, где ОАР достигает $560 \mathrm{Б \kappa} / \mathrm{M}^{3}$ [31].

По данным материалов ГГП «Березовгеология» за 1993-1995 гг. (В.Г. Пахомов, Ю.П. Попов и др.) была составлена карта радоноопасных регионов на территории юга Западно-Сибирской плиты (рис. 4). Районы города Белокурихи и пгт. Колывань отнесены к потенциально опасным по ОАР.
В строительных нормах и правилах СП 11-102-97 «Инженерно-экологические изыскания для строительства» указано, что при превышении ППР с по-

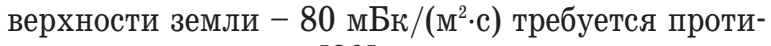
ворадоновая защита [30].

Для всех исследуемых районов, кроме пгт. Колывань в Новосибирской области, средние ППР соответствуют нормам, однако в некоторых точках наблюдаются аномально высокие показания, достигающие $620 \pm 76$ мБк $/\left(\mathrm{m}^{2} \cdot c\right)$ - г. Чжухай в Китае.

Дополнительным фактором радиационной нагрузки на местное население в г. Чжухай может служить высокая активность торона $\left({ }^{220} \mathrm{Rn}\right.$ или $\mathrm{Tn})$ - дочернего продукта ${ }^{232} \mathrm{Th}$. Период полураспада Tn составляет 52 с, поэтому он обычно не представляет радиоэкологической опасности. Однако в южно-китайских провинциях за счет распространения ториеносных пород и почв, а также использования в строительстве глин и щебня, обогащённых ${ }^{232} \mathrm{Th}$, наблюдается аномальная активность $\mathrm{Tn}$ (до 461 кБк/м³) [27].

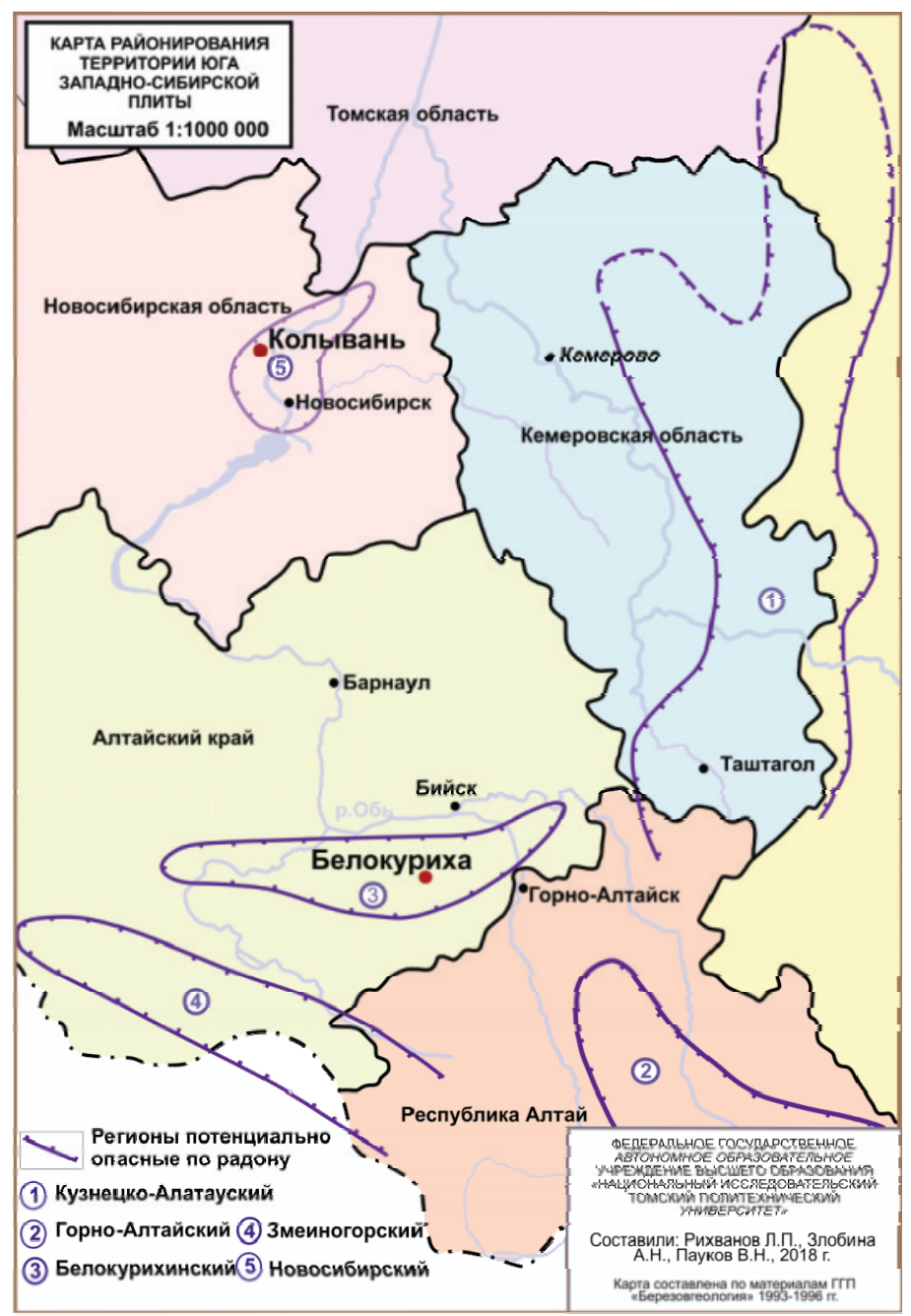

Рис. 4. Карта радоноопасных районов на территории юга Западно-Сибирской плиты по данным материалов ГГП «Березовгеология». Масштаб 1:1000000

Fig. 4. Map of radon exposure risk within the territory of the West-Siberian plate, based on the data from state geological enterprise «Berezovgeologiya». Scale 1:1000000 
Для оценки состояния радиационной безопасности населения используется показатель радиационного риска. Расчеты выполнены согласно указаниям «Порядок ведения радиационно-гигиенических паспортов организаций и территории» [32].

Установлено, что на всех исследуемых территориях наблюдается опасная радиационная обстановка. Это обусловлено тем, что 1 Бк/ $\mathrm{m}^{3} \mathrm{Rn}$ при вдыхании создает эквивалентную эффективную дозу (ЭЭД) в 0,05 мЗв/год при регламенте 2,4 мЗв/год и приемлемом уровне 5 мЗв/год от природных источников излучения [33].

Расчеты показали, что в районе г. Белокуриха суммарная (прогнозируемая) доза от всех природных источников облучения составит $10,7 \pm 2,1$ мЗв/год. Предыдущие исследования показали $8,7 \pm 1,5$ мЗв/год [31]. В районе Колыванского гранитного карьера значения ЭЭД достигают 17,3 $\pm 3,3$ мЗв/год. По данным В.В. Селегея средний уровень в Новосибирске составляет 5,9 мЗв/год [34]. Высокие значения ЭЭД $14,7 \pm 4$ мЗв/год - наблюдаются в районе г. Чжухай (Китай). Исследования Н. Morishima и др. установили средний уровень ЭЭД в южных провинциях Китая - 5,9 мЗв/год [35]. В районе г. Эшасьер во Франции ЭЭД тоже превышает норму и достигает значения 7,5 1,2 мЗв/год.

\section{Анализ статистических параметров заболеваемости в районах распространения радиоактивных гранитоидов}

Опасность высоких концентраций ЕРЭ в гранитах обусловлена их тесной связью с повышением активностей $\mathrm{Rn}$ в условиях выветривания пород, a также их влиянием на геохимический состав подземных вод. Помимо влияния канцерогенного $\mathrm{Rn}$ на здоровье населения, фактором риска может выступать участие ЕРЭ в трофических цепях порода-вода-почва-растение-животное-человек. Повышение уровня общего радиационного фона может отрицательно сказываться на эпидемиологическом статусе населения.

В районах исследования для анализа показателей здоровья населения были использованы статистические данные по заболеваемости ЗНО легкого, носоглотки, кроветворной ткани (лейкоз), а также анемией и ВПР. Обобщающим показателем уровня заболеваемости населения является число зарегистрированных пациентов с впервые установленным диагнозом на 100 тыс. человек $(\%$ о0о0).

Доказано, что радиация имеет более высокий уровень воздействия на детей, чем на взрослых $[3,4]$. В связи с этим в табл. 3 приведены показатели первичной заболеваемости для различных возрастных групп населения.

При сопоставлении первичных показателей заболеваемости $3 \mathrm{HO}$ у всех групп населения с российскими и мировыми показателями отмечаются превышения уровня заболеваемости во всех исследуемых районах. В целом частота заболеваемости у взрослых (от 18 лет и выше) отличается от пока- зателей заболеваемости у детей (от 0 до 14 лет) в большую сторону, оба значения превышают стандартизированные уровни по РФ и миру.

Белокуриха, Алтайский край. При сопоставлении первичных показателей заболеваемости $3 \mathrm{HO}$ в г. Белокуриха с общероссийскими и мировыми показателями отмечаются превышения уровня заболеваемости у детей (от 0 до 14 лет) в 2,8 раза. В 2015 г. отмечается высокая детская заболеваемость ЗНО кроветворной ткани - $7 \%$ о000, что выше среднероссийских показателей в 2 раза. В 2015 г. уровень заболеваемости 3 НО головного мозга у детей от 0 до 14 лет составил $35 \%$ о0о0, всероссийский стандарт $-2,1 \%$ ㅇo [36].

Согласно докладу «0 состоянии санитарно-эпидемиологического благополучия населения в Алтайском крае в 2016 году», Белокуриха отнесена к территориям «риска» относительно краевых показателей заболеваемости органов дыхания (бронхитом, астмой и др.), крови и кроветворных органов (анемии и др.), инсулинзависимым сахарным диабетом первого типа и первичной инвалидности детей [37].

Снижение качества окружающей среды (загрязнение атмосферного воздуха, питьевых вод и др.) создает опасность неинфекционной заболеваемости. Однако уровень загрязнения атмосферного воздуха в Белокурихе в 2014-2016 гг. приближается $\kappa$ нулевым значениям и соответствует гигиеническим нормам. Качество питьевой воды в Белокурихе соответствует санитарно-эпидемиологическим требованиям [37, 38]. В связи этим можно предположить, что основным фактором риска заболеваемости кроветворных органов, органов дыхания и ЗНО в Белокурихе может служить повышенная ОАР (рис. 3) и МЭД до 40 мкР/ч.

Кольвань, Новосибирская область. Первичная заболеваемость $3 \mathrm{HO} \mathrm{у} \mathrm{детей} \mathrm{(от} 0$ до 14 лет) и взрослых (от 18 лет и старше) в пгт. Колывань Новосибирской области больше в 4 и 1,5 раза показателей по РФ соответственно. Также в Колывани выявлены высокие уровни заболеваемости 3 НО легкого (в 9 раз выше показателя по РФ), кроветворной ткани у всего населения (в 11 раз выше показателя по РФ) и у детей от 0 до 14 лет (в 14 раз выше показателя по РФ). Уровень заболеваемости анемиями и ВПР среди детского населения выше стандартов по РФ в 1,5 раза. В 2015 г. отмечен высокий показатель ЗНО яичка у детей от 0 до 14 лет - $26 \%$ о РФ этот стандарт не превышает $1 \%$ [000 [36].

Высокие уровни заболеваемости в Колывани могут быть следствием загрязнения атмосферного воздуха в связи с близким расположением карьера по добыче радиоактивного гранита открытым способом, высокими показателями ОАР и ППР (рис. 3) и использованием местного гранита $(U-9,6$ г/т, Th - 34 г/т) и щебня в строительных целях, что повышает уровень радиационного фона до 35 мкP/ч.

Гуандун, Китай. По данным Всемирной организации здравоохранения южные провинции Китая являются районами с самым высоким в мире показателем заболеваемости ЗНО носоглотки. 
Таблица 3. Сводная таблица показателей заболеваелости (\% (ш) за 2010-2017 г2. в районах повышенного радиоэкологического риска Table 3. $\quad$ Summary table of incidence $(\% 000)$ in 2010-2017 in areas with high radiological risk

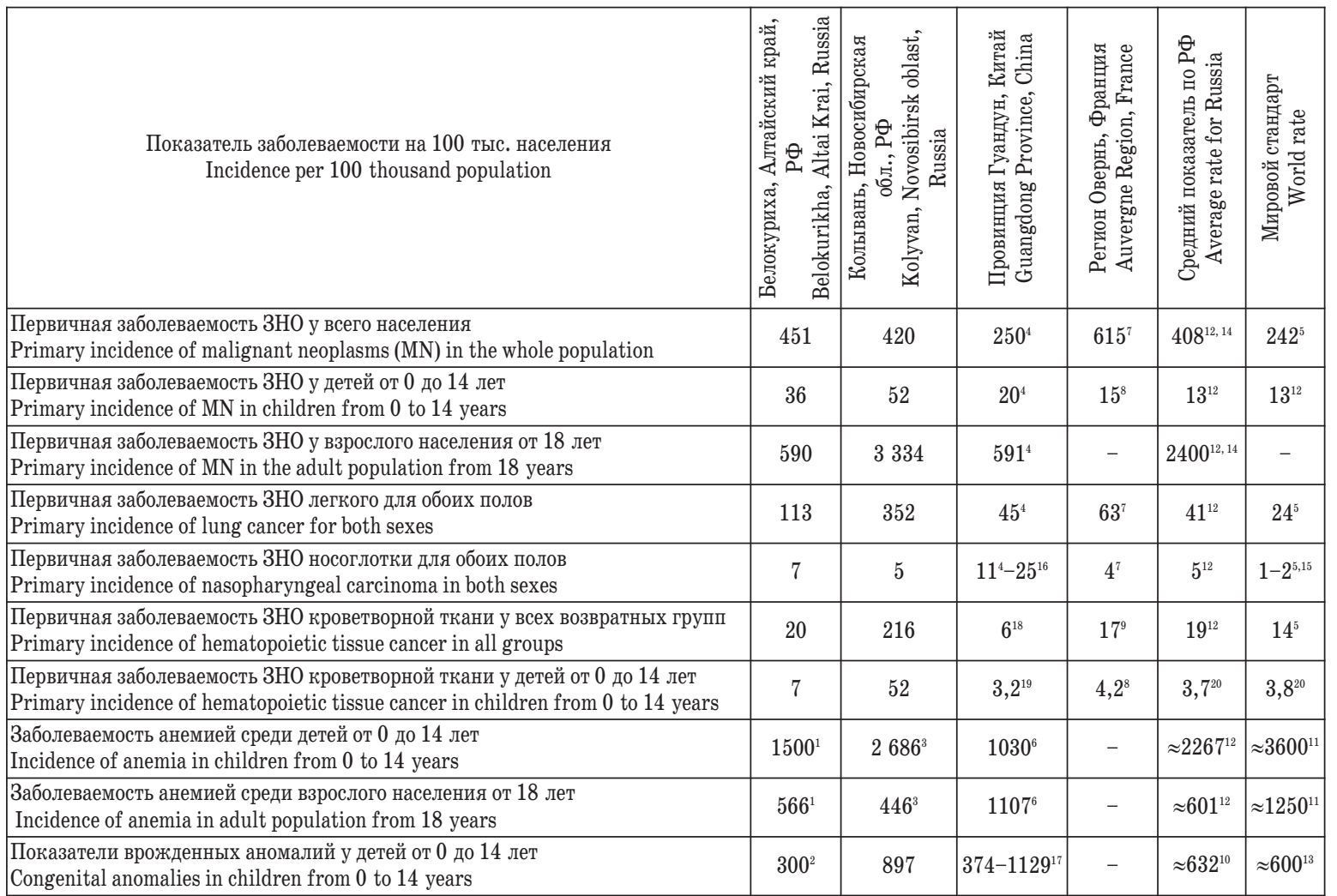

- нет данных; ${ }^{1}$ - Доклад, 2017 г. [37]; ${ }^{2}-$ Социально-гигиенический паспорт, 2017 г. [38]; ${ }^{3}$ - Государственный доклад, 2015 г. [39]; ${ }^{4}$ - R. Meng et al., 2016 [40]; ${ }^{5}$ - A. Jemal et al., 2014 [41]; ${ }^{6}$ - X.M. Xu et al., 2004 [42]; ${ }^{7}$ - Le cancer en Auvergne, 2015 [43]; ${ }^{8}-$ F. Isfan et al., 2007 [44]; ${ }^{9}-$ E. Chatignoux, 2012 [9]; ${ }^{10}$ - Н.С. Демикова и др., 2015 г. [45]; ${ }^{11}-$ Worldwide prevalence of anaemia, 2008 [46 ]; ${ }^{12}-3 л$ локачественные новообразования в России, 2018 2. [47]; ${ }^{13}$ - J.I. Hoffman et al., 2002 [48]; ${ }^{14}$ - G. Salem, 2006 [49]; ${ }^{15}$ - L.L. Tang et al., 2016 [50]; ${ }^{16}$ - C.S. Ho, 2017 [51 ]; ${ }^{17}$-Y.Qu et al., 2016 [52]; ${ }^{18}$ - W. Chen et al., 2014 [53]; ${ }^{19}$ - J. Ma et al., 2008 [54]; ${ }^{20}-$ E.M.Akceль u 2p., 2009 2. [36]

- no data; ${ }^{1}$ - Report, 2017 [37]; ${ }^{2}$ - Socio-hygienic passport, 2017 [38]; ${ }^{3}$ - State report, 2015 [39]; ${ }^{4}-$ R. Meng et al., 2016 [40]; ${ }^{5}-$ A. Jemal et al., 2014 [41]; ${ }^{6}$ - X.M. Xu et al., 2004 [42]; ${ }^{7}$ - Le cancer en Auvergne, 2015 [43]; ${ }^{8}-$ F. Isfan et al., 2007 [44]; ${ }^{9}-$ E. Chatignoux, 2012 [9]; ${ }^{10}$ - N.S. Demikova et al., 2015 [45]; ${ }^{11}-$ Worldwide prevalence of anaemia, 2008 [46]; ${ }^{12}$ - Malignant neoplasms in Russia, 2018 [47]; ${ }^{13}$ - J.I. Hoffman et al., 2002 [48]; ${ }^{14}$ - G. Salem, 2006 [49]; ${ }^{15}$ - L.L. Tang et al., 2016 [50]; ${ }^{16}$ - C.S. Ho, 2017 [51]; ${ }^{17}$-Y. Qu et al., 2016 [52]; ${ }^{18}$ - W. Chen et al., 2014 [53]; ${ }^{19}$ - J. Ma et al., 2008 [54]; ${ }^{20}-$ E.M.Aksel et al., 2009 [36]

В провинции Гуандун выявлено 11-25 случаев заболеваний 3 НО носоглотки для обоих полов на 100 тыс. населения [40, 51]. В России этот показатель варьирует от 2 до 7 случаев на 100 тыс. населения, в мире - от 1 до $2[47,50]$. В свою очередь в провинции Гуандун выявлена повышенная частота ВПР, заболеваемости $3 \mathrm{HO} \mathrm{у} \mathrm{детей,} \mathrm{анемией} \mathrm{и}$ ЗНО легкого среди взрослого населения.

В некоторых районах провинции наблюдаются аномально высокие показания ОАР и ППР (рис. 3). В провинции Гуандун широко распространено строительство домов из кирпичей, сделанных из местной радиоактивной глины (U - 8,5 г/т, Th 53,4 г/т). Дополнительным фактором радиационной нагрузки на местное население в г. Чжухай может служить высокая активность торона $\left({ }^{220} \mathrm{Rn}\right.$ или $\mathrm{Tn}$ ) - дочернего продукта ${ }^{232} \mathrm{Th}$. Период полураспада Tn составляет 52 с, поэтому он обычно не представляет радиоэкологической опасности. Однако в южно-китайских провинциях за счет распространения ториеносных пород и почв, а также использования в строительстве глин и щебня, обогащённых ${ }^{232} \mathrm{Th}$ наблюдается аномальная активность ${ }^{220} \mathrm{Tn}$ (по данным N. Wang - до 461 кБк/ $\mathrm{m}^{3}$ ).

Овернь, Франция. Показатель ЗНО у всех групп населения во французском регионе Овернь превышает мировой стандарт в 3 раза. Онкозаболевания легкого отличаются повышенным уровнем относительно мировых значений и стандартизированных показателей по Франции [43].

Высокие содержания U (18 г/т) в гранитах и, как следствие, высокие активности Rn (300 Бк/ м $\left.^{3}\right)$ могут выступать опасными радиоэкологическими факторами, влияющими на заболеваемость и смертность населения в регионе Овернь.

\section{Заключение}

По результатам геохимических, минералогических, радиоэкологических и медико-статистических исследований в районах залегания высокорадиоактивных гранитоидов (Белокуриха, Колывань, Эшасьер, Чжухай) установлено: 
1) в процессах коро- и почвообразования ЕРЭ высвобождаются из структурных решеток акцессорных минералов (монацит, циркон, ксенотим и др.) и сорбируются на глинистых минералах (каолинит, монтмориллонит вермикулит и др.);

2) данный процесс - одна из причин повышения радоно- и тороновыделений, а также радиационного фона;

3) существует связь опасной радиоэкологической обстановки природного и природно-техногенного происхождения с повышенными уровнями врожденных пороков развития, заболеваемости злокачественными новообразованиями у населения;

4) отмечается превышение уровня заболеваемости во всех исследуемых районах при сопоставлении первичных показателей заболеваемости ЗНО у всех групп населения с российскими и мировыми показателями (на 100 тыс. населения, $\%$ о0о0). В целом частота заболеваемости у взрослых (от 18 лет и выше) отличается от по-

\section{СПИСОК ЛИТЕРАТУРЫ}

1. Boyce J.D. Ionizing radiation // Cancer Epidemiology and Prevention / Eds. D. Schottenfeld, J.F. Fraumeni. - Oxford: University Press, 2006. - P. 259-293.

2. UNSCEAR: Sources and effects of ionizing radiation. Report to the General Assembly of the United Nations with Scientific Annexes, United Nations sales publication, E.94.IX.2. - New York: United Nations, 1993. - 920 p.

3. UNSCEAR: United National Scientific Committee on the Effects of Atomic Radiation. UNSCEAR 2000 Report to General Assembly, Sources and Effects of Ionizing Radiation. - New York: United Nations, 2000. - $897 \mathrm{p}$.

4. UNSCEAR: United Scientific Committee on the Effects of Atomic radiation. UNSCEAR 2006 Report: Annexe E: Source-to-effects assessment for radon in homes and work places. - New York: United Nations, 2009. - $334 \mathrm{p}$.

5. Residential radon and small cell lung cancer. A systematic review / A. Rodríguez-Martínez, M. Torres-Durán, J.M. Barros-Dios, A. Ruano-Ravina / / Cancer Letters. - 2018. - V. 426. - P. 57-62.

6. Henshaw D.L., Allen J.E. Is indoor radon linked to leukaemia in children and adults? A review of the evidence // Natural Ionizing radiation and health. Proc. from a symposium. - 0tta: AIT Enger A/S, 2002. - P. 110-125.

7. Comparative analyses of studies of childhood leukemia and magnetic fields, radon and gamma radiation / L. Kheifets, J. Swanson, Y. Yuan, C. Kusters, X. Vergara // Journal of Radiological Protection. - 2017. - V. 37. - № 2. - P. 459-491.

8. Komperød M., Friberg E.G., Rudjord A.L. Radiation Doses to the Norwegian Population. Summary of radiation doses from planned exposure and the environment. - Østerås: Norwegian Radiation Protection Authority, 2015. - № 13. - $19 \mathrm{p}$.

9. Chatignoux É., Pépin P. Atlas de la mortalité par cancer en Ile-deFrance 2000-2007. - Paris: Observatoire régional de santé d'Ilede-France, 2012. - $140 \mathrm{p}$.

10. Bølviken B. Ecological analysis: nasopharyngeal carcinoma and multiple sclerosis versus radioactive elements // Natural Ionizing Radiation and Health. Proc. from a symposium. - Oslo, 2001. - P. 126-134.

11. Radiological risk from thoron, a case study: the particularly radon-prone area of Bolsena, and the lesson learned / G. Cinelli, B. Capaccioni, M.A. Hernández-Ceballos, D. Mostacci, A. Perghem, L. Tositti // Radiation Physics and Chemistry. 2015. - № 116. - P. 381-385. казателей заболеваемости у детей (от 0 до 14 лет) в большую сторону, оба значения превышают стандарты по РФ и миру;

5) к территориям "риска» по частоте заболеваемости ЗНО легкого можно отнести Белокуриху в Алтайском крае $(113 \%$ о0о0 $)$ и Колывань в Новосибирской области $(352 \%$ 0000), ЗНО носоглотки провинцию Гуандун $(11-25 \%$ \%о00), ЗНО кроветворной ткани - Колывань (все возрастные группы - $216 \%$, миям - Гуандун $(1107 \%$ \%о00), по ВПР - Гуандун $(374-1129 \%$ о о000 и Колывань $(897 \%$ о000).

6) вклад естественной радиоактивности в общий комплекс факторов, влияющих на показатели заболеваемости, установить достаточно сложно. Однако необходимо учитывать воздействие радиационных рисков при оценке некоторых медико-биологических показателей здоровья населения, особенно в районах распространения радиоактивных пород.

12. Winde F., Ewald E., Gerhard G. Uranium contaminated drinking water linked to leukaemia - Revisiting a case study from South Africa taking alternative exposure pathways into account // Science of the Total Environment. - 2017. - № 574. - P. 400-421.

13. Бахур A.Е. Научно-методические основы радиоэкологической оценки геологической среды: автореф. дис.... д-ра г.-м. наук. M., 2008. -45 c.

14. Табакаева Е.М. Петролого-геохимические критерии рудоносности Белокурихинского комплекса Алтая: автореф. дис.... канд. г.-м. наук. - Томск, 2011. - 21 с.

15. Государственная геологическая карта Российской Федерации. Масштаб 1:1000000 (третье поколение). Серия Алтае-Саянская. Лист N-44 - Новосибирск. Объяснительная записка / Г.А. Бабин, А.И. Черных, А.Г. Головина, С.В. Жигалов и др. СПб.: Картографическая фабрика ВСЕГЕИ, 2015. - 392 с.

16. Кузьмин А.М., Паршин П.Н. 0 геолого-структурном положении Обского гранитоидного массива // Известия Томского политехнического института. - 1976. - Т. 289. - С. 51-57.

17. Mapping the terrestrial air-absorbed gamma dose rate based on the data of airborne gamma-ray spectrometry in southern cities of China / Shengqing Xiong, Wang Nanping, Zhengguo Fan, Xingming Chu, Qifan Wu, Shaoying Pei, Jianhua Wan, Lihui Zeng // Journal of Nuclear Science and Technology. - 2012. - № 49:1. - P. 61-70.

18. Chen P. Regional Geology of Guangdong Province. - Beijing: Geological Publishing House, 1988. -345 p.

19. Li J., Long Y., Lu W. Discussion on the genesis of the ion-adsorption REE deposits in Jiangmen area, Guangdong province // West-China Exploration Engineering. - 2005. - № 113. P. 101-103.

20. Рундквист Д.В. и др.Крупные и суперкрупные месторождения рудных полезных ископаемых: в 3 т. - М.: ИГЕМ РАН, 2006. T. 1: Глобальные закономерности размещения. -390 c.

21. Breiter K., Frŷda J., Leichmann J. Phosphorus and rubidium in alkali feldspars: case studies and possible genetic interpretation // Bulletin of the Czech Geological Survey. - 2002. - V. 77. - № 2. P. 93-104.

22. Cuney M., Marignac C., Weisbrod A. The Beauvoir Topaz-Lepidolite Albite Granite (Massif Central, France): the Disseminated Magmatic Sn-Li-Ta-Nb-Be Mineralization // Economic Geology. 1992. - V. 87. - P. 1766-1794.

23. Григорьев Н.А. Распределение химических элементов в верхней части континентальной коры. - Екатеринбург: Ур0 РАН, 2009. -383 c. 
24. Bowen H.J.M. Trace elements in biochemistry. - London; New York: Academic Press, 1966. - 248 p.

25. The nature of high soil radioactivity in Chinese province Guangdong / L.P. Rikhvanov, A.N. Zlobina, N. Wang, I.A. Matveenko // Procedia Chemistry. - 2014. - V. 10. - P. 460-466.

26. Микляев П.С., Петрова Т.Б. Исследования эманирования глинистых пород по радону // Геоэкология. Инженерная геология. Гидрогеология. Геокриология. - 2010. - № 1. - С. 13-22.

27. Wang N., Peng A., Xiao L. The level and distribution of ${ }^{220} \mathrm{Rn}$ concentration in soil-gas in Guangdong province, China / Radiation Protection Dosimetry. - 2012. - V. 152. - № 1-3. - P. 204-209.

28. French population exposure to radon, terrestrial gamma and cosmic rays / S. Billon, S. Morin et al. // Radiation Protection Dosimetry. - 2005. - V. 113. - № 3. - P. 314-320.

29. Нормы радиационной безопасности (НРБ-99): Гигиенические нормативы СП 2.6.1.758-99. - М.: Минздрав России, 1999. $116 \mathrm{c.}$

30. СП 11-102-97 «Инженерно-экологические изыскания для строительства». Госстрой России. - М: ГУП ЦПП, 2001. - 20 с.

31. Азаев Ю.Л. Радиационно-гигиеническая обстановка в предгорьях Алтая и ее оптимизация на курорте Белокуриха: автореф. дис. ... канд. мед. наук. - Кемерово, 1997. - 25 с.

32. Методические указания. Порядок ведения радиационно-гигиенических паспортов организаций и территории, № 239 , 66/288. Государственный комитет Российской Федерации по охране окружающей среды, 1999. - КонсультантПлюс. URL: http://www.consultant.ru/document/cons_doc_LAW_24508/ a6d9529fed281803a61f5cdbf85d684798b85b83/ (дата обращения 17.01.2019).

33. СанПиН 2.6.1.2800-10 «Гигиенические требования по ограничению облучения населения за счет источников ионизирующего излучения», постановление от 24.12.2010. Федеральная служба по надзору в сфере защиты прав потребителей и благополучия человека, 2010. Техэксперт. URL: http://docs. cntd.ru/document/902256355 (дата обращения 20.01.2019).

34. Селегей В.В. Радиоактивное загрязнение г. Новосибирска прошлое и настоящее: пособие по экологическому образованию населения. - Новосибирск: Институт катализа им. Г.К. Борескова, 1997. - 145 с.

35. Morishima H., Koga T., Tatsumi K. Dose Measurement, its Distribution and Individual External Dose Assessments of Inhabitants in the High Background Radiation Areas in China // Journal of Radiation Research. - 2000. - № 41. - P. 9-23.

36. Аксель Е.М., Горбачева И.А. Заболеваемость детей злокачественными новообразованиями и смертность от них в России и странах СНГ в 2007 г. // Вестник РОНЦ им. Н.Н. Блохина РАМН. - 2009. - Т. 20. - № 3. Прил. 1. - С. 139-156.

37. Доклад «0 состоянии санитарно-эпидемиологического благополучия населения в Алтайском крае в 2016 году». ФБУЗ «Центр гигиены и эпидемиологии в Алтайском крае». - Барнаул: ГудАрт, 2017. - 151 с.

38. Социально-гигиенический паспорт Алтайского края по врожденным порокам развития у детей (плода) (на основе социально-гигиенического паспорта за 1997-2016 гг.). Информационный бюллетень. - Барнаул: РИТТЕР. - 2017.- 129 с.

39. Государственный доклад «0 состоянии санитарно-эпидемиологического благополучия населения в Новосибирской области в 2014 году». - Новосибирск, «Альфа-Порте», 2015.- 226 с.

40. Cancer incidence and mortality in Guangdong province, 2012 / Meng Ruilin, Wei Kuangrong, Xia Liang, Xu Yanjun, Chen
Wanqing, Zheng Rongshou, Lin Lifeng // Chinese Journal of Cancer Research. - 2016. - V. 28. - № 3. - P. 311-320.

41. The Cancer Atlas. Second ed. / A. Jemal, P. Vineis, F. Bray, L. Torre, D. Forman. - Atlanta, GA: American Cancer Society, 2014. $-136 \mathrm{p}$

42. The prevalence and spectrum of a and $b$ thalassaemia in Guangdong Province: implications for the future health burden and population screening / X.M. Xu, Y.Q. Zhou, G.X. Luo, C. Liao, M. Zhou, P.Y. Chen, J.P. Lu, S.Q. Jia, G.F. Xiao, X. Shen, J. Li, H.P. Chen, Y.Y. Xia, Y.X. Wen, Q.H. Mo, W.D. Li, Y.Y. Li, L.W. Zhuo, Z.Q. Wang, Y.J. Chen, C.H. Qin, M. Zhong // Journal of clinical pathology. - 2004. - V. 57. - № 5. - P. 517-522.

43. Le cancer en Auvergne / F. Bourdillon, P. Pépin, G. Spaccaferri, E. Vaissière, M. Vincent, N. Vincent // Bulletin de veille sanitaire. -2015 . - № 30. -19 p.

44. Incidence et survie des cancers de l'enfant en Auvergne-Limousin, France, 1986-2003 / F. Isfan, P. Blouin, P. Gembara, C. Piguet, J. Chazal, L. de Lumley, F. Demeocq, J. Kanold // Bulletin Epidémiologique Hebdomadaire. - 2007. - № 14. - C. 116-119.

45. Динамика частоты врожденных пороков развития в РФ (по данным федеральной базы мониторинга ВПР за 2006-2012 гг.) / Н.С. Демикова, А.С. Лапина, М.А. Подольная, Б.А. Кобринский // Российский вестник перинатологии и педиатрии. 2015. - № 2. - C. 72-77.

46. Worldwide prevalence of anaemia 1993-2005: WHO global database on anaemia / Eds. B. de Benoist, E. McLean, I. Egli, M. Cogswell. - Geneva: World Health Organization, 2008. - 51 p.

47. Злокачественные новообразования в России в 2016 году (заболеваемость и смертность) / под ред. А.Д. Каприна, В.В. Старинского, Г.В. Петровой. - М.: МНИОИ им. П.А. Герцена филиал ФГБУ «НМИЦ радиологии» Минздрава России, 2018. -250 c.

48. Hoffman J.I., Kaplan S. The incidence of congenital heart disease // Journal of the American College of Cardiology. - 2002. - V. 19. № 39. - P. 1890-1900.

49. Salem G., Libbey J. Atlas de la sante en France. V. 2. Comportements Et Maladies. - Paris: John Libbey Eurotext, 2006. - 222 p.

50. Tang L.L., Chen W.Q., Xue W.Q. Global trends in incidence and mortality of nasopharyngeal carcinoma // Cancer Letters. 2016. - № 374. - P. 22-30.

51. Ho C.S. Beating «Guangdong cancer»: a review and update on nasopharyngeal cancer // Hong Kong Medical Journal. - 2017. V. 23. - № 5. - P. 497-502.

52. Incidence of Congenital Heart Disease: the 9-Year Experience of the Guangdong Registry of Congenital Heart Disease, China / Y. Qu, X. Liu, J. Zhuang, G. Chen, J. Mai, X. Guo // PLoS ONE. - 2016. - V. 11. - № 7. - P. 1-12.

53. Cancer incidence and mortality in China, 2014 / W. Chen, K. Sun, R. Zheng, H. Zeng, S. Zhang, C. Xia, Z. Yang, H. Li, X. Zou, J. He // Chinese Journal of Cancer Research. - 2018. - V. 30. - № 1. P. 1-12.

54. Ma J., Lei Y., Ye T. Study on the ecological association between natural radioactivity and childhood leukemia in Guangdong province // China Journal Epidemiology. - 2008. - V. 29. - № 4. P. 343-345. In Chinese. 


\section{Информация об авторах}

Злобина A.H., аспирант Инженерной школы природных ресурсов Национального исследовательского Томского политехнического университета; ассистент кафедры геологии и полезных ископаемых Башкирского государственного университета.

Рихванов Л.П., доктор геолого-минералогических наук, профессор отделения геологии Инженерной школы природных ресурсов Национального исследовательского Томского политехнического университета.

Барановскал H.В., доктор биологических наук, профессор отделения геологии Инженерной школы природных ресурсов Национального исследовательского Томского политехнического университета.

Фархутдинов И.М., кандидат геолого-минералогических наук, доцент кафедры геологии и полезных ископаемых Башкирского государственного университета.

Ванг Нанпинг, доктор наук в области геофизики, профессор школы геофизики и информационных технологий Китайского геологического университета. 
UDC $504.05 ; 550.42$

\title{
RADIOECOLOGICAL HAZARD FOR THE POPULATION LIVING IN THE REGIONS WITH HIGH RADIOACTIVE GRANITES
}

\author{
Anastasiya N. Zlobina ${ }^{12}$, \\ anastasiyazl@mail.ru \\ Leonid P. Rikhvanov', \\ rikhvanov@tpu.ru \\ Natalia V. Baranovskaya', \\ nata@tpu.ru \\ Iskhak M. Farkhutdinov², \\ iskhakgeo@gmail.com

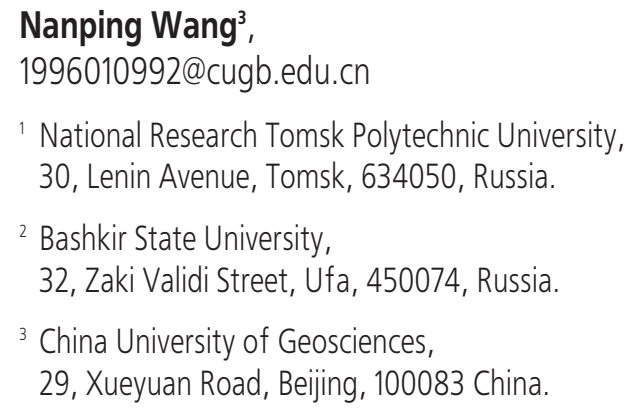

The relevance of the research is caused by the need to explain the high morbidity in the areas of radioactive rocks and soils. The study was carried out in the framework of a new scientific field - Medical Geology.

The main aim is to define the volume of radon emission in the area of high-radioactive granite outcrops and evaluate their radiological hazard and medical-biological consequences.

Objects: geochemical and mineralogical composition of granite, weathering crusts and soils, the volume of radon emission and incidence in various regions of the world (Zhuhai city in Guangdong Province, China; the town of Échassières in Auvergne region, France; the town of Belokurikha in Altai Krai, Russia; and urban-type settlement Kolyvan, Novosibirsk Oblast, Russia).

Methods: a wide range of methods including instrumental neutron activation, $x$-ray phase analysis, gamma spectrometry, fragmentation radiography, electron microscopy, express measurement of radon volume activity, calculation of radon density flux, equivalent effective dose and the frequency of newly detected diseases (incidence) were used in the research.

Results. The current article provides the summarized data on the effects of ionizing radiation on the human body. According to the results of geochemical, mineralogical, radioecological and medical-statistical studies the authors have revealed that the radionuclides are released from the structural lattices of accessory minerals and sorbed on clay minerals at soil formation. This process contributes to the increase of radon emission and background radiation. The high activity of radon ( $R n$ ) and the elevated concentrations of radioactive elements in the underlying rocks and soils lead to the increase in disease rates including some types of cancer, anemias, and congenital defects. The territories of «risk» in the incidence of lung cancer include Belokurikha in the Altai Krai and Kolyvan in the Novosibirsk Oblast; nasopharyngeal cancer - Guangdong province; hematopoietic tissue cancer - Kolyvan; anemia - Guangdong; congenital malformations - Kolyvan.

\section{Key words:}

Radiation, uranium, thorium, radon, granites, soils, radioecological problems, morbidity, incidence,

Radioecology, Medical Geology, Geoecology, Guangdong, Auvergne, Belokurikha, Kolyvan.

\section{REFERENCES}

1. Boyce J.D. Ionizing radiation. Cancer Epidemiology and Prevention. Eds D. Schottenfeld, J.F. Fraumeni. Oxford, University Press, 2006. pp. 259-293.

2. UNSCEAR: Sources and effects of ionizing radiation. Report to the General Assembly of the United Nations with Scientific Annexes. New York, United Nations, 1993.920 p.

3. UNSCEAR: United National Scientific Committee on the Effects of Atomic Radiation. UNSCEAR 2000. Report to General Assembly, with Scientific Annexes, Sources and Effects of Ionizing Radiation. New York, United Nations, 2000. 897 p.

4. UNSCEAR: United Scientific Committee on the Effects of Atomic radiation.UNSCEAR2006 Report: Annexe E: Source-to-effects as- sessment for radon in homes and work places. New York, United Nations, 2009. 334 p.

5. Rodríguez-Martínez A., Torres-Durán M., Barros-Dios J.M., Ruano-Ravina A. Residential radon and small cell lung cancer. A systematic review. Cancer Letters, 2018, vol. 426, pp. 57-62.

6. Henshaw D.L., Allen J.E. Is indoor radon linked to leukaemia im children and adults? A review of the evidence. Natural Ionizing radiation and health. Proc. from a symposium. Otta, 2002. AIT Enger A/S. pp. 110-125.

7. Kheifets L., Swanson J., Yuan Y., Kusters C., Vergara X. Comparative analyses of studies of childhood leukemia and magnetic fields, radon and gamma radiation. Journal of Radiological Protection, 2017, vol. 37, no. 2, pp. 459-491. 
8. Komperød M., Friberg E.G., Rudjord A.L. Radiation Doses to the Norwegian Population. Summary of radiation doses from planned exposure and the environment. Østerås, Norwegian Radiation Protection Authority, 2015. No. 13, 19 p.

9. Chatignoux É., Pépin P. Atlas de la mortalitépar cancer en Ile-deFrance 2000-2007 [Atlas of mortality from cancer on Ile-deFrance in 2000-2007]. Paris, Observatoire régional de santé d'Ile-de-France, 2012. 140 p. In Fr.

10. Bølviken B. Ecological analysis: nasopharyngeal carcinoma and multiple sclerosis versus radioactive elements. Natural Ionizing Radiation and Health. Proc. from a symposium. Oslo, 2001. pp. $126-134$.

11. Cinelli G., Capaccioni B., Hernández-Ceballos M.A., Mostacci D., Perghem A., Tositti L. Radiological risk from thoron, a case study: the particularly radon-prone area of Bolsena, and the lesson learned. Radiation Physics and Chemistry, 2015, no. 116, pp. 381-385.

12. Winde F., Ewald E., Gerhard G. Uranium contaminated drinking water linked to leukaemia - Revisiting a case study from South Africa taking alternative exposure pathways into account. Science of the Total Environment, 2017, no. 574, pp. 400-421.

13. Bahur A.E. Nauchno-metodicheskie osnovy radioekologicheskoy otsenki geologicheskoy sredy. Avtoreferat Dis. Dokt. nauk [Scientific-methodical bases of the radio-ecological assessment of the geological environment. Dr. Diss. Abstract]. Moscow, 2008. 45 p.

14. Tabakaeva E.M. Petrologo-geokhimicheskie kriterii rudonosnosti Belokurikhinskogo kompleksa Altaya. Avtoreferat Dis. Kand. nauk [Petrological-geochemical criteria of ore content of the Belokurikha complex in Altai. Kand. Diss. Abstract]. Tomsk, 2011. $21 \mathrm{p}$.

15. Babin G.A., Chernykh A.I., Golovina A.G., Zhigalov S.V. Gosudarstvennaya geologicheskaya karta Rossiyskoy Federatsii. Masshtab 1:1000000 (tretye pokoleniye). Seriya Altaye-Sayanskaya. List N-44 - Novosibirsk. Obyasnitelnaya zapiska [The State Geological Map of the Russian Federation. Scale 1:1000000. Altai-Sayan Series. Sheet no. 44 - Novosibirsk. Explanatory note]. St-Petersburg, Kartograficheskaya fabrika VSEGEI Publ., 2015. $392 \mathrm{p}$.

16. Kuzmin A.M., Parshin P.N. 0 geologo-strukturnom polozhenii Obskogo granitoidnogo massiva [About the geological and structural position of the $0 \mathrm{~b}$ granitoid massif]. Izvestiya Tomskogo Politekhnicheskogo instituta, 1976, vol. 289, pp. 51-57.

17. Shengqing Xiong, Wang Nanping, Zhengguo Fan, Xingming Chu, Qifan Wu, Shaoying Pei, Jianhua Wan, Lihui Zeng. Mapping the terrestrial air-absorbed gamma dose rate based on the data of airborne gamma-ray spectrometry in southern cities of China. Journal of Nuclear Science and Technology, 2012, vol. 49, no. 1, pp. $61-70$.

18. Chen P. Regional Geology of Guangdong Province. Beijing, Geological Publishing House, 1988. 245 p.

19. Li J., Long Y., Lu W. Discussion on the genesis of the ion-adsorption REE deposits in Jiangmen area, Guangdong province. WestChina Exploration Engineering, 2005, no. 113, pp. 101-103.

20. Rundkvist D.V. Krupnye i superkrupnye mestorozhdeniya rudnykh poleznykh iskopaemykh [Large and super-large deposits of ore minerals]. T. 1. Globalnye zakonomernosti razmeshcheniya [Vol. 1. Global laws of arrangement]. Moscow, IGEM RAN Publ., 2006. P. 390.

21. Breiter K., Frŷda J., Leichmann J. Phosphorus and rubidium in alkali feldspars: case studies and possible genetic interpretation. Bulletin of the Czech Geological Survey, 2002, vol. 77, no. 2, pp. $93-104$.

22. Cuney M., Marignac C., Weisbrod A. The Beauvoir Topaz-Lepidolite Albite Granite (Massif Central, France): the Disseminated Magmatic Sn-Li-Ta-Nb-Be Mineralization. Economic Geology, 1992, vol. 87, pp. 1766-1794.
23. Grigorev N.A. Raspredelenie khimicheskikh elementov v verkhney chasti kontinentalnoy kory [Distribution of chemical elements in the upper continental crust]. Ekaterinburg, UrO RAN Publ., 2009. $383 \mathrm{p}$.

24. Bowen H.J.M. Trace elements in biochemistry. London; New York, Academic Press, 1966. 248 p.

25. Rikhvanov L.P., Zlobina A.N., Wang N., Matveenko I.A. The nature of high soil radioactivity in Chinese province Guangdong. Procedia Chemistry, 2014, vol. 10, pp. 460-466.

26. Miklyaev P.S., Petrova T.B. Issledovaniya emanirovaniya glinistykh porod po radonu [Studies of radon emanation in clay rocks]. Geoekologiya. Inzhenernaya geologiya. Gidrogeologiya. Geokriologiya, 2010, no. 1, pp. 13-22.

27. Wang N., Peng A., Xiao L. The level and distribution of ${ }^{220} \mathrm{Rn}$ concentration in soil-gas in Guangdong province, China. Radiation Protection Dosimetry, 2012, vol. 152, no. 1-3, pp. 204-209.

28. Billon S., Morin S. French population exposure to radon, terrestrial gamma and cosmic rays. Radiation Protection Dosimetry, 2005, vol. 113, no. 3, pp. 314-320.

29. Normy radiatsionnoy bezopasnosti (NRB-99). Gigienicheskie normativy SP 2.6.1.758-99 [Radiation safety standards (NRB-99). Higenic norms]. Moscow, Minzdrav Rossii Publ., 1999. 116 p.

30. SP 11-102-97. Inzhenerno-ekologicheskie izyskaniya dlya stroitelstva [Engineering and environmental surveys for construction]. Gosstroy Rossii. Moscow, GUP CPP, 2001. 20 p.

31. Azaev Yu.L. Radiatsionno-gigienicheskaya obstanovka v predgoryakh Altaya i ee optimizatsiya na kurorte Belokurikha. Avtoreferat Dis. Kand. nauk [Radiation and hygienic situation in the $\mathrm{Al}-$ tai foothills and its optimization in Belokurikha resort. Cand. Diss. Abstract]. Kemerovo, 1997. 25 p.

32. Metodicheskie ukazaniya. Poryadok vedeniya radiatsionno-gigienicheskikh pasportov organizatsii i territorii № 239, 66/288 [The order of radiation-hygiene passports of organizations and territories no. 239, 66/288]. Gosudarstvenny komitet Rossiyskoy Federatsii po okhrane okruzhayushchey sredy, 1999. KonsultantPlyus. Available at: http://www.consultant.ru/document/cons_doc_LAW_24508/a6d9529fed281803a61f5cdbf85d6 84798b85b83/ (accessed 17 January 2019).

33. SanPiN 2.6.1.2800-10 Gigienicheskie trebovaniya po ogranicheniyu oblucheniya naseleniya za schet istochnikov ioniziruyushchego izlucheniya [Hygienic requirements to limit public exposure from ionizing radiation sources]. Federalnaya sluzhba po nadzoru v sfere zashchity prav potrebiteley i blagopoluchiya cheloveka, 2010. Tekhehkspert. Available at: http://docs.cntd.ru/document/902256355 (accessed 20 January 2019).

34. Selegey V.V. Radioaktivnoe zagryaznenie g. Novosibirska proshloe i nastoyashchee: posobie po ekologicheskomu obrazovaniyu naseleniya [Radioactive contamination of Novosibirsk - past and present: manual on environmental education of the population]. Novosibirsk, Institut kataliza im. G.K. Boreskova, 1997. $145 \mathrm{p}$.

35. Morishima H., Koga T., Tatsumi K. Dose Measurement, Its Distribution and Individual External Dose Assessments of Inhabitants in the High Background Radiation Areas in China. Journal of Radiation Research, 2000, no. 41, pp. 9-23.

36. Aksel Ye.M., Gorbacheva I.A. Morbidity and mortality of children with malignant neoplasms in Russia and CIS countries in 2007. Bulletin of the RNTS named after N.N. Blokhin RAMS, 2009, vol. 20, no 3, pp. 139-156.

37. Doklad. 0 sostoyanii sanitarno-epidemiologicheskogo blagopoluchiya naseleniya $v$ Altayskom krae $v 2016$ godu [On the state of sanitary and epidemiological welfare of the population in the Altai region in 2016]. FBUZ Centr gigieny i epidemiologii v Altayskom krae. Barnaul, GoodArt, 2017. 151 p.

38. Sotsialno-gigienichesky pasport Altayskogo kraya po vrozhdennym porokam razvitiya u detey (ploda) (na osnove sotsialno-gigi- 
enicheskogo pasporta za 1997-2016 gg.) [Socio-hygienic passport of the Altai territory on congenital malformations of the children (fetus) (based on social-hygenic passport for 1997-2016)]. Barnaul, RITTER Publ., 2017. 129 p.

39. Gosudarstvenny doklad. 0 sostoyanii sanitarno-epidemiologicheskogo blagopoluchiya naseleniya $v$ Novosibirskoy oblasti $v$ 2014 godu [On the state of sanitary and epidemiological welfare of Novosibirsk region population in 2014]. Novosibirsk, AlfaPorte Publ., 2015. 226 p.

40. Meng Ruilin, Wei Kuangrong, Xia Liang, Xu Yanjun, Chen Wanqing, Zheng Rongshou, Lin Lifeng. Cancer incidence and mortality in Guangdong province, 2012. Chinese Journal of Cancer Research, 2016, vol. 28, no. 3, pp. 311-320.

41. Jemal A., Vineis P., Bray F., Torre L., Forman D. The Cancer Atlas. Second ed. Atlanta, GA, American Cancer Society, 2014. $136 \mathrm{p}$.

42. Xu X.M., Zhou Y.Q., Luo G.X., Liao C., Zhou M., Chen P.Y., Lu J.P., Jia S.Q., Xiao G.F., Shen X., Li J., Chen H.P., Xia Y.Y., Wen Y.X., Mo Q.H., Li W.D., Li Y.Y., Zhuo L.W., Wang Z.Q., Chen Y.J., Qin C.H., Zhong M. The prevalence and spectrum of a and $b$ thalassaemia in Guangdong Province: implications for the future health burden and population screening. Journal of clinical pathology, 2004, vol. 57, no. 5, pp. 517-522.

43. Bourdillon F., Pépin P., Spaccaferri G., Vaissière E., Vincent M., Vincent N. Le cancer en Auvergne [Cancer in Auvergne]. Bulletin de veille sanitaire, 2015, no. 30, 19 p. In Fr.

44. Isfan F., Blouin P., Gembara P., Piguet C., Chazal J., De Lumley L., Demeocq F., Kanold J. Incidence et survie des cancers de l'enfant en Auvergne-Limousin, France, 1986-2003. Bulletin Epidémiologique Hebdomadaire, 2007, no. 14, pp. 116-119.

45. Demikova N.S., Lapina A.S., Podolnaya M.A., Kobrinskiy B.A. Trends in the incidence of congenital malformations in the Russian Federation (according to the 2006-2012 Congenital Malformations Monitoring Base data). Rossiyskiy vestnik perinatologii $i$ pediatrii, 2015, no. 2, pp. 72-77. In Rus.
46. Worldwide prevalence of anaemia 1993-2005: WHO global database on anaemia. Eds. B. de Benoist, E. McLean, I. Egli, M. Cogswell. Geneva, World Health Organization, 2008. 51 p.

47. Zlokachestvennye novoobrazovaniya v Rossii $v 2016$ godu (zabolevaemost $i$ smertnost) [Cancer in Russia in 2016 (morbidity and mortality)]. Eds. A.D. Kaprin, V.V. Starinsky, G.V. Petrova. Moscow, P.A. Gertsen MNIOI - branch of FGBU NMIC of Radiology of Ministry of Health of the Russian Federation, 2018. $250 \mathrm{p}$.

48. Hoffman J.I., Kaplan S. The incidence of congenital heart disease. Journal of the American College of Cardiology, 2002, vol. 19 , no. 39, pp. 1890-1900.

49. Salem G., Libbey J. Atlas de la sante en France. Vol. 2. Comportements Et Maladies [Atlas of health in France]. Paris, John Libbey Eurotext, 2006. 220 p. In Fr.

50. Tang L.L., Chen W.Q., Xue W.Q. Global trends in incidence and mortality of nasopharyngeal carcinoma. Cancer Letters, 2016, no. 374, pp. $22-30$.

51. Ho C.S. Beating "Guangdong cancer»: a review and update on nasopharyngeal cancer. Hong Kong Medical Journal, 2017, vol. 23, no. 5, pp. 497-502.

52. Qu Y., Liu X., Zhuang J., Chen G., Mai J., Guo X. Incidence of Congenital Heart Disease: the 9-Year Experience of the Guangdong Registry of Congenital Heart Disease, China. PLOS ONE, 2016, vol. 11, no. 7, pp. 1-12.

53. Chen W., Sun K., Zheng R., Zeng H., Zhang S., Xia C., Yang Z., Li H., Zou X., He J. Cancer incidence and mortality in China, 2014. Chinese Journal of Cancer Research, 2018, vol. 30, no. 1, pp. 1-12.

54. Ma J., Lei Y., Ye T. Study on the ecological association between natural radioactivity and childhood leukemia in Guangdong province. China Journal Epidemiology, 2008, vol. 29, no. 4, pp. 343-345. In Chinese.

Received: 4 February 2019.

\section{Information about the authors}

Anastasiya N. Zlobina, postgraduate student, National Research Tomsk Polytechnic University; assistant, Bashkir State University.

Leonid P. Rikhvanov, Dr. Sc., professor, National Research Tomsk Polytechnic University.

Natalia V. Baranovskaya, Dr. Sc., professor, National Research Tomsk Polytechnic University.

Iskhak M. Farkhutdinov, Cand. Sc., head of department, Bashkir State University.

Nanping Wang, Dr. Sc., professor, China University of Geosciences. 